\title{
Unemployment and house price crises: Lessons for Fiscal Policy from the Dutch Recession
}

\author{
Coen N Teulings
}

Correspondence: Cnt23@cam.ac.uk University of Cambridge,

Cambridge, UK

\begin{abstract}
Since the beginning of the financial crisis in 2008 , the Dutch economy lost $6 \%$ of gdp relative to Germany, even though the Netherlands (unlike the GIPSI countries) did not face serious problems to finance its sovereign debt. This bad performance is explained by the interaction of fiscal policy and the housing market. This makes the Netherlands an interesting case because these effects can be analyzed in isolation of stress on financial markets. We sketch a simple overlapping generation framework. House price declines lead to a temporary drop in consumption, forcing a reallocation of labour from domestic to tradable industries. This leads to a loss in industry specific human capital, causing a jump in unemployment. The analysis yields a number of lessons for fiscal policy in the aftermath of a financial crisis and for the current EU framework for the evaluation of member states' fiscal policy. Fiscal policy provided too little intergenerational insurance and the EU framework is an obstacle to do that. JEL codes: E32, E62 and J64

Keywords: House price crises; Fiscal policy
\end{abstract}

\section{Introduction}

Exactly at the day of the bankruptcy of Lehman Brothers, the Dutch finance minister, Wouter Bos, published his budget. The preamble to this budget summarized the state of Dutch economy in rosy words. Sovereign debt was at its lowest point since WW II and was expected to decline further. For many years, the Dutch unemployment rate was among the lowest in Europe, while GDP per capita was among the highest. The prospects for further growth of the economy were good. The Dutch government had little to worry about, so it seemed.

As we know now, history has proven otherwise. The demise of Lehman has pushed the world economy in a deep recession, of which it is still trying to recover. The subsequent euro-crisis has reinforced the problems. Many European countries are now struggling to get their economy growing and their deficit under control. However, there are striking differences within Europe. The GIPSI countries with limited access to financial markets face massive losses in GDP. The Netherlands does not have problems to finance its sovereign debt. Nevertheless, its economy lost 6\% output relative to Germany between 2008 and 2014. This paper offers an explanation for this phenomenon, which provides broader lessons for the mechanisms at work in economies hit by a financial crisis. Since financing its public debt was not immediately at risk, the Netherlands is an ideal laboratory for these mechanisms. These lessons might then be helpful in avoiding financial stress in the first place and for the proper design of the European framework for budgetary oversight in the second place.

(C) 2014 Teulings; licensee Springer. This is an Open Access article distributed under the terms of the Creative Commons Attribution License (http://creativecommons.org/licenses/by/2.0), which permits unrestricted use, distribution, and reproduction in any medium, provided the original work is properly credited. 
The key factor for understanding the underperformance of the Dutch economy is the interaction between fiscal policy and a house price slump. The pressure on house prices had three causes. The first cause is the fall in GDP relative to its pre-crisis trend. Cerra and Saxena (2008) and Teulings and Zubanov (2013) have shown that the fall in output after a financial crisis is largely permanent, in the order of magnitude of 5 to $10 \%$ of GDP. Hence, consumers loose life time wealth and therefore have to reduce their consumption of housing services. The second cause is the stress in the banking system due to financial crisis. This reduces their willingness to provide credit for buying houses. However, both causes have affected Germany and The Netherlands alike, and hence they cannot by themselves explain the difference in performance between both countries. A third factor was specific to the Netherlands. The country ran an extremely generous system of tax deductibility of mortgage interest rates, costing about 2 to $3 \%$ of GDP in terms of lower tax revenues. This system has been perceived as unsustainable by organisations like IMF, OECD, and EU, but more importantly, also by the Dutch public. When the crisis hit, the system lost its credibility. These factors lead to a fall in house prices, which will be shown to be equivalent to a transfer of wealth from current to future generations. The former lose, since they get a lower price for their property. The latter gain since they have to pay less. This wealth transfer tightens the lifetime budget constraint of the current generation. In response to this, they reduce their consumption to compensate these losses. Only as current generations gradually die, having solved their financial stress by lowering consumption, and are replaced by new generations that have not experienced a loss of wealth, consumption will pick up again. During this transition, reduced consumption has a profound effect on the distribution of employment between industries. In a small open economy, the main option for a country to save is to export to other countries. Hence, employment in the export industry has to grow while the domestic sector and construction have to shrink. Relocation of employment between industries is costly. Workers have specific human capital for a particular industry. Small reallocations of labour between industries can be accommodated by incumbent workers retiring and new cohorts choosing to work in different industries. However, this mechanism is too slow for large shifts in demand. Then, incumbent workers have to change industries. This requires retraining of workers who have already acquired their industry specific human capital. The old human capital has to be written off. The larger is the fall in consumption, the greater is the shift in employment, and hence, the larger the value of human capital to which this applies.

There has been a lot of discussion on the role of institutions for the persistence of unemployment. Minimum wages hamper the creation of new vacancies. Employment protection legislation frustrates the reallocation of labour to more productive ventures. Unemployment benefits undermine the incentives for wage adjustment in the previous job, for seeking a new job, and for acquiring new human capital. Wage rigidity forces firms in declining industries to fire workers instead of being able to compete at lower cost. The current model sees no role for the first two factors and some role for the final two, Countries with generous unemployment benefits will find workers accepting lay off more easily and finding a new job more slowly. Countries with lack of wage flexibility will find firms laying off workers more easily. However, we shall show that a proper fiscal policy can avoid a part of the reallocation of labour in the first place. 
The actual magnitude of the fall in consumption depends on fiscal policy. If fiscal policy is contractionary in the transition period, this will further increase the share of burden of the financial crisis that is put on the shoulders of current generations. They will reduce their consumption even further, requiring an even larger shift of employment to the export industry. Instead, the government can provide intergenerational insurance by adopting an offsetting expansionary fiscal policy, shifting part of the burden of adjustment to future generations. Lack of intergenerational insurance will lead to overshooting in the reallocation of labour between industries and will therefore increase the loss in specific human capital. Dutch fiscal policy was indeed highly contractionary from 2011 onwards.

A badly understood feature of policy reforms reducing the tax deductibility of mortgage interest is that these reforms imply a transfer of wealth from current to future generations. Even a balanced budget reform, which ploughs back all extra tax revenues from lower interest deductibility by lower tax rates, still leads to a wealth transfer. Current house prices reflect the net discounted value of the entitlement to future deductibility. For future generations, the system is a wash. They pay higher house prices in exchange for the entitlement to tax deductibility. Likewise, the abolishment of the system is a wash: the net discounted value of lower deductibility cancels against higher house prices. Hence, the current generation bears the full loss of the net discounted value of deductibility. Offsetting this intergenerational transfer of wealth would require the government to increase its debt, by pre-emptively reducing tax rates. If not, the fall in house prices induced by the reform of the system contributes to the fall in current consumption.

This reasoning sounds Keynesian in nature. Remarkably, it does not require much wage- or price-stickiness. It is not John Maynard Keynes' consumption function, but Milton Friedman's permanent income hypothesis that runs the show. All problems are due to a missing intergenerational insurance markets, or more precisely, the unwillingness of European politicians to provide this insurance.

Similar mechanisms have played in other European countries experiencing slumps on the housing market. Some of these countries (like Spain and Ireland) lived above their means, as shown by deficits on their current account. The Netherlands is a special case. The country has a large surplus on its current account but nevertheless faces a house price slump and a budget deficit exceeding EU's 3\% threshold (Denmark was the only country in a comparable situation). Nevertheless, our analysis offers a number of broader lessons. The three main lessons are summarized here. First, a surge in sovereign debt is a natural consequence of a house-price slump. Attempting to stop the rise in sovereign debt actually makes things worse. Secondly, this rise is not a short run phenomenon. The periodicity of intergenerational effects implies that an episode of rising debt may last 10 years or more. Thirdly, the output gap and the structural balance are not useful indicators of the structural situation of public finance, since they insufficiently account for the long run effects.

The setup of the paper is as follows. Section 2 provides some empirical background for the discussion, both on the situation of the Dutch economy and on some broader issues. Section 3 describes the theoretical framework. It deserves more rigorous numerical testing. For the moment, this remains an exercise for future research. Section 4 discusses the adjustment path of this economy to a shock of the type that hit the Dutch 
economy. Section 5 discusses some caveats and compares the Dutch experience to other countries. Finally, Section 6 draws conclusions.

\section{Empirical background}

Why did the Dutch economy lag behind that of Germany? Figure 1 provides some first answers to this question. The figure shows the (expected) evolution of gdp for six European countries from 2008 to 2014 and its decomposition by expenditure categories. The green line is an index of the level of gdp, starting from $2008=100$. Output fell by about $3 \%$ in 2009 . Relative to trend this is equivalent to a decline of about $5 \%$, consistent with the estimates by Cerra and Saxena (2008) and Teulings and Zubanov (2013) on the impact of financial crises on gdp. Both studies show that this output loss is largely permanent. This is a puzzling conclusion, since it is hard to understand why the effect of a financial crisis should be in GDP permanent loss. We leave this issue aside here.

In the period after 2009, the path of gdp starts to diverge between countries. Apart from the crisis countries Spain and Ireland, growth in the Netherlands lagged behind. The output loss relative to Germany, Belgium, and France is 6, 4, and 2\% respectively in 2014. The decomposition by expenditure categories shows that the differences between countries are largely due to private consumption and investment in housing, with the exception of France which has difficulty in selling on global markets. Note that we have to apply a different scale for Spain and Ireland, because the magnitude of the

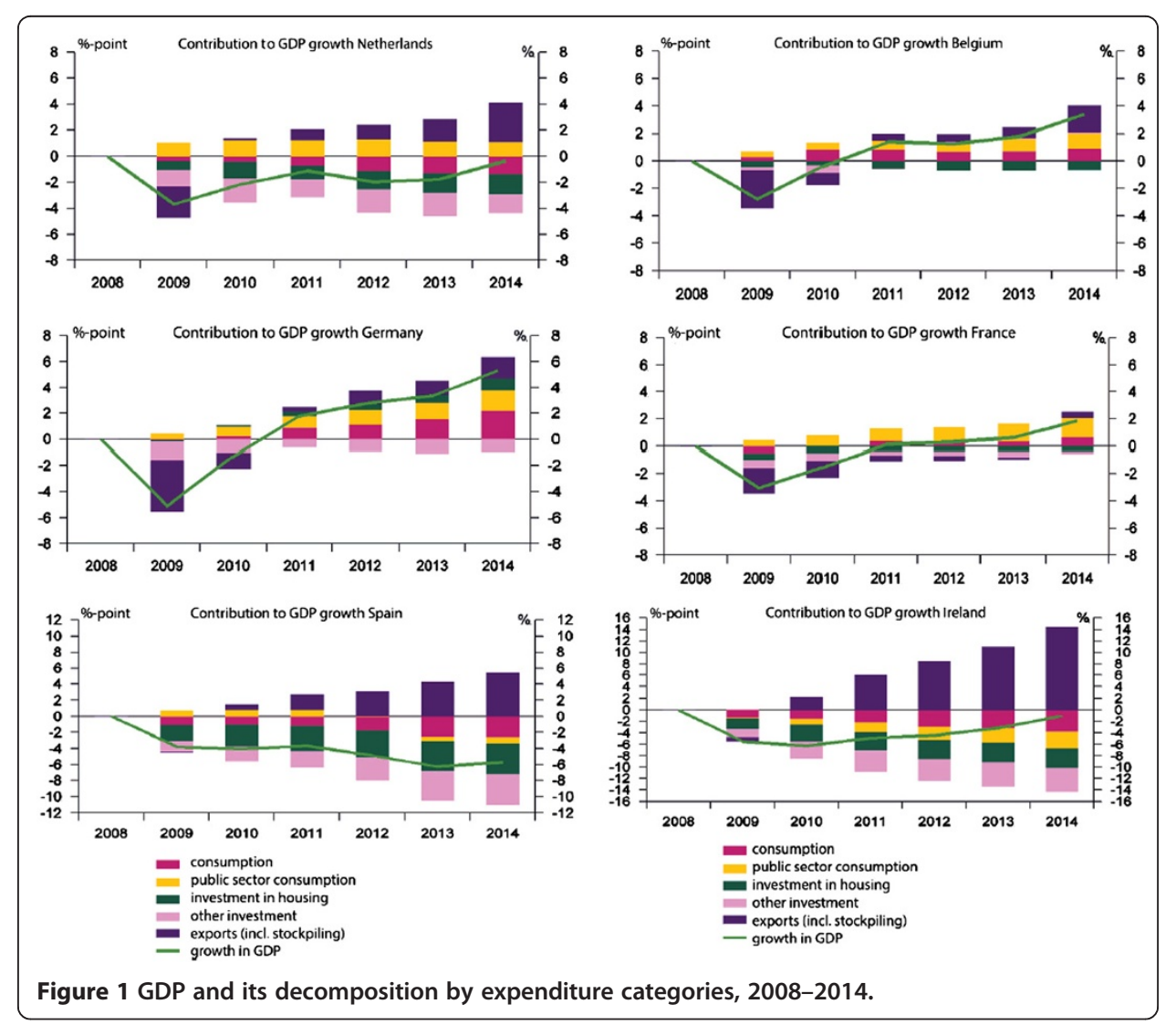


effects in these countries dwarfs anything happening elsewhere. The graph shows that the lagging behind of the Dutch economy is not a competiveness problem. Domestic consumption and the collapse in investment in housing are the culprits. This is confirmed by the evidence on the Dutch current account, which runs a surplus of almost $10 \%$ of GDP, one of the largest in the EU.

There are two candidate explanations for the decline of domestic demand in the Netherlands: the slump in house-prices and fiscal policy. First, consider house prices. Countries that had large house price declines saw substantial increases in unemployment, see Figure 2. Spain, Denmark, Ireland, the UK, the Netherlands, and the US had both house price slumps and increasing unemployment. A detailed comparison of Denmark and the Netherlands is particularly revealing. Both countries are in many aspects similar. Both have a deep mortgage market as can be seen from the size mortgage debt relative to gdp, see SER (2013, Table two). ${ }^{1}$ Both have an extensive system of pension funds. However, they differ in the timing of the house price decline. Where house prices started to fall in Denmark immediately after the demise of Lehman, the house price decline did not get momentum in the Netherlands until 2011. This difference is
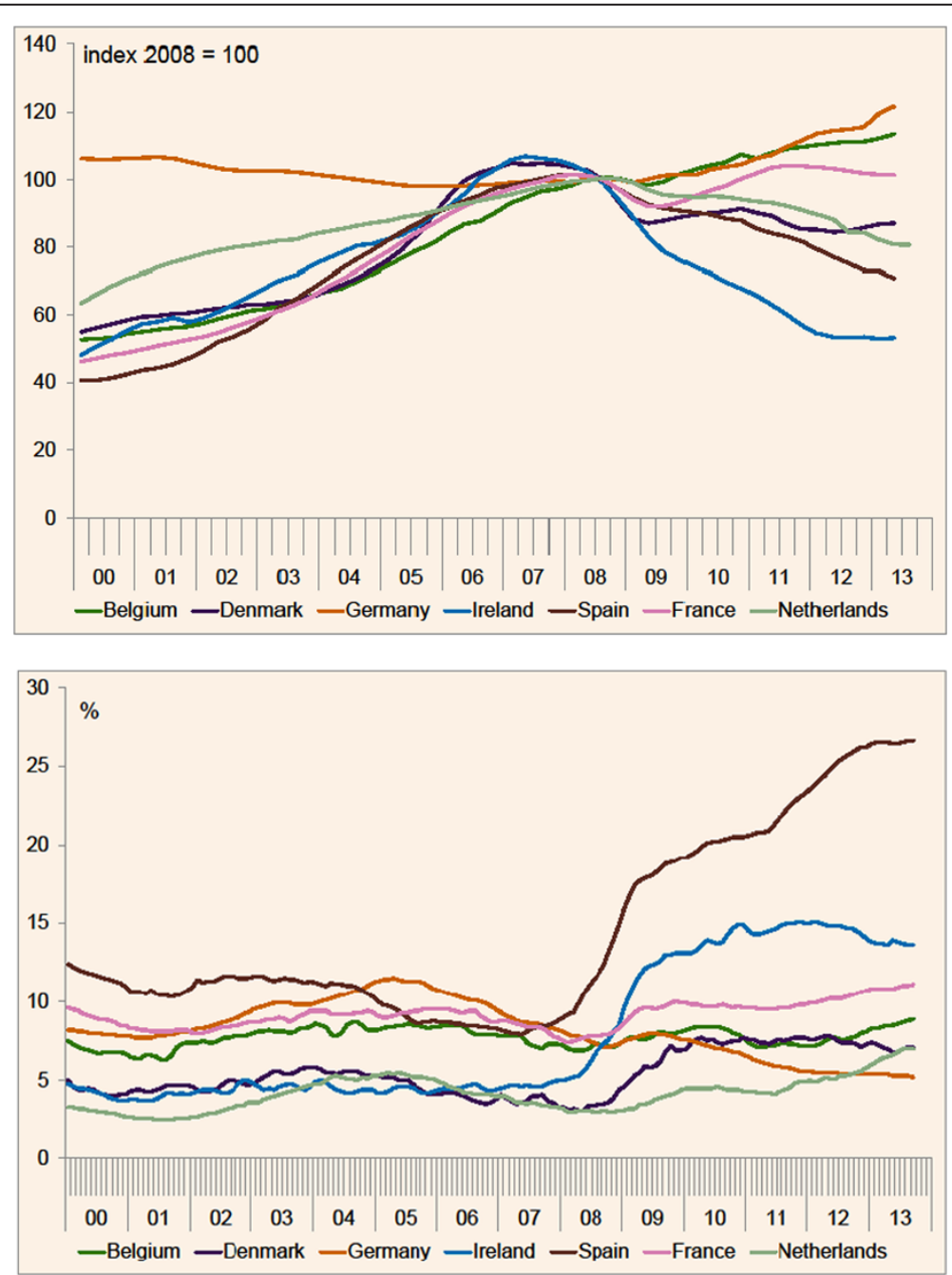

Figure 2 House prices and unemployment, 2007-2013. 
exactly reflected in the timing of the rise in unemployment: it started in Denmark immediately in 2009, while in the Netherlands the initial increase was limited, from 3.1\% in 2008 to $4.5 \%$ in 2010. There was even a slight decline in 2011. Only from 2012 onwards, unemployment surged to $7.5 \%$ in 2014 . This is consistent with the notion that house prices declines are an important driver of unemployment.

The Netherlands ran a very generous system of tax deductibility of mortgage interest payments. All interest payments are tax deductible at marginal tax rates of $42 \%$ or $52 \%$. Since interest received on saving accounts is tax free, this opens opportunities for tax arbitrage between mortgage debt and savings accounts. Interest only mortgages that benefit from interest deductibility over the full duration of the loan are combined with separate savings accounts for repaying the loan at the end of its duration. This system pushed up Loan-to-Value and Loan-to-Income ratio's and made funding of homepurchases cheap. Initially, this system has merely pushed up house prices. ${ }^{2}$ Since most of this system has been in place for a long time, and to the extent that the supply of housing is price elastic, part of this upward pressure on prices will have been offset by an increase in supply, eventually pushing house prices back to the cost of production. Since the system has been in place for some time in 2008, it must have been in equilibrium by that time. In that equilibrium, the consumption of housing services was higher than it would have been without mortgage subsidies. A study by CPB for the Commissie Sociaal-Economische Deskundigen (2010) reports that the system raised long run house prices by $10 \%$.

There has been some discussion, fuelled by the IMF and the Economist, whether house prices in the Netherlands were overvalued on the onset of the crisis in 2008, since they had gone up steeply since 1986 . However, house-prices were extremely low at that time due to a deep slump in house prices from 1978 to 1985, see Bénétrix et al. (2012). Moreover, a comparison of prices of apartments in major cities across Western Europe lends little support to the view that house prices were overvalued in Amsterdam, apart from the upward effect of about $10 \%$ of the tax deductibility of mortgage interest payments as discussed before. Excluding London and Paris for their sheer size, prices in Amsterdam do not seem to be out of line with other cities, see Social and Economic Council (2013, Figure five). Finally, house-prices increases were particularly high in the second half of the 1990's. This was the period when employment grew quickly, fuelled by a rapid increase in female labour supply. Moreover, during that period, banks began to allow applicants for mortgages to add up the incomes of both partners for the calculation of loan-to-income ratios.

Another issue is whether the house price decline might be attributed to a lower willingness of banks to provide mortgage funding as a result of the financial crisis. Clearly, there is a chicken-egg problem. The fall in house prices pushed many house "under water" (value of their home being below the value of their mortgage) and raised loanto-value ratios, which makes banks' mortgage portfolios less save assets, even though delinquency rate remained very low compared to international standards. Banks therefore wanted to reduce their mortgage portfolio. The easiest way to achieve that is not issuing new loans. This reinforced the downward pressure on house prices.

The first two years after the Lehman bankruptcy, fiscal policy was largely neutral. However, the new government taking office in 2010 set out immediately for an extensive austerity program of 19 billion (3\% of gdp) to meet its EU obligations. Halfway its 
formal term in office, the growth of gdp lagged behind its forecast in 2010. The government thought this to be unacceptable. This was motivated partly by its desire to obey its European obligations, which the government had advocated in the preceding period to apply to other countries. Hence, it set out to agree on a further austerity package of 9 billion (1.5\% of gdp). The coalition parties failed to reach agreement. Hence, the government fell and new elections were organized. In the run up to the election, the minister of finance, Jan Kees de Jager, managed to reach agreement with a number of opposition parties on this austerity package. This episode shows the wide support among both Dutch politicians and voters for austerity. This confirms findings of Brender and Drazen $(2005,2008)$ that classical theories of the political business cycle no longer apply in mature democracies. Voters dislike politicians who run large deficits and politicians are therefore prone to avoid the stigma of being a spender. ${ }^{3}$ Immediately after the election, the forecast for gdp deteriorated even further. In an attempt to nevertheless meet the 3\% target, the parties participating in the bargaining on the new coalition agreed on an additional 15 billion ( $2.5 \%$ of gdp) austerity program. In the course of 2013, prospects deteriorated even further, invoking the government to agree on a final austerity package of 6 billion (1\% of gdp). Hence, between 2010 and 2013, the government decided on an austerity program of altogether $8 \%$ of gdp to be implemented in the period 2010-2017. There might be debate on some double counting, on the exact timing of the proposed policies, and on their effectiveness actually improving the budget (as always, there was some window dressing), but there can be no doubt that this is by far the largest set of austerity measures since WW II.

Figure 3 documents that financing public debt has not been an issue for the Netherlands. The interest rates for Dutch sovereign bonds moved largely parallel to those for Germany, the difference between both countries being in the order of magnitude 30 basis points since 2011, compared to several hundreds for countries like Ireland and Spain. This makes the Netherlands an interesting case, since it can be used to analyse the effect of falling house-prices in isolation of the effect of the changes of a country's access to financial markets.

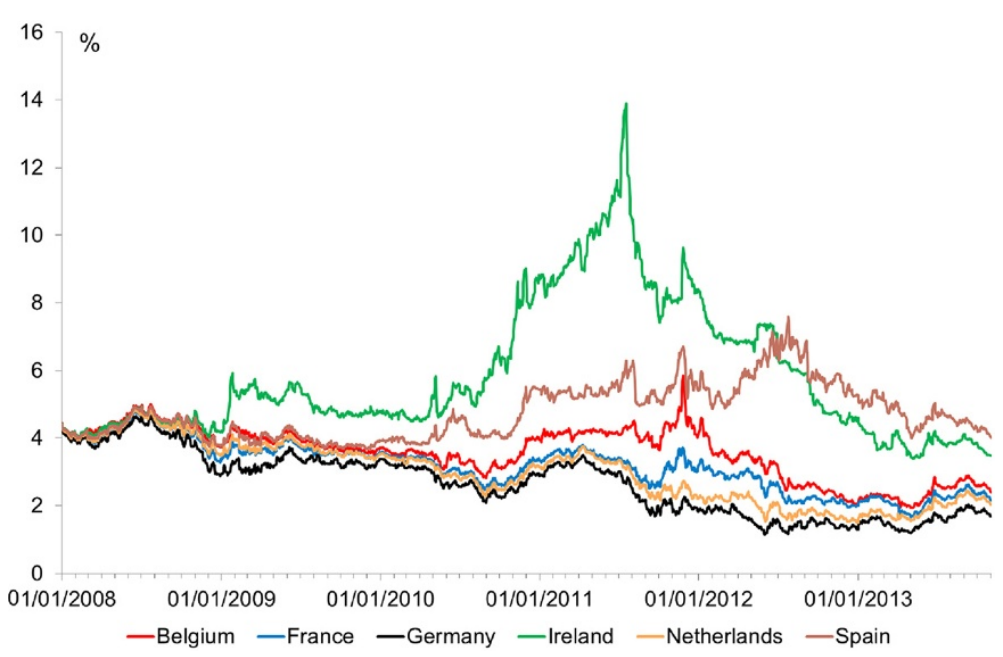

Figure 3 Ten year government bond rates, 2008-2013. 
Table 1 provides some further background material on the economic impact of financial crises, drawn from Reinhart and Rogoff (2009). The table list the average peak-totrough impact of a crisis on a number of key variables: income, unemployment, sovereign debt, house- and equity-prices. The message of the table is simple: the impact of financial crises is large and persistent, consistent with the findings of Cerra and Saxena (2008) and Teulings and Zubanov (2013). This applies in particular to unemployment. Where unemployment is mean reverting in normal times and does so rather quickly (estimated impulse response functions suggest that an initial shock is undone in 4 to 5 years), unemployment is far more persistent after financial crises. Again, house price slumps play an important role in these crises. House prices come down by $36 \%$ on average. Both observations play an important role in the theoretical framework laid out in the next section. The main idea is that financial crises imply a substantial loss in wealth for an economy, to a large extent due to the decline in the value of housingproperty, which forces the economy to save more. Case et al. (2013) report an effect of housing wealth on consumption of 3 to $5 \%$. Shifting the economy from consumption to saving implies a transformation of the inter-industry distribution of employment from domestic and construction towards tradables.

Figure 4, taken from (Mian and Amir 2010, Mian and Amir 2012), provides evidence on this shift in the production structure of economies facing house price crises. The figure documents the evolution of employment in the tradable and non-tradable industries as a function of the initial debt-to-income ratios, using cross section variation between US counties. Mian and Sufi use initial debt-to-income ratios, because they argue that it is mainly the fall in aggregate demand that causes the problem, not the reallocation of labour away from construction. In our model that distinction is less relevant, since both phenomena are two sides of the same coin. The crisis causes a negative wealth effect, leading to a fall in domestic demand which invokes a reallocation of labour from construction and domestics towards tradables. The latter is exactly what Mian and Sufi document. Counties hit harder by the crisis saw large declines in employment in domestics and hardly any effect in tradables. This job loss translates almost entirely in a surge in unemployment. In our interpretation, this reflects the fact that workers have industry specific human capital that is lost when changing industries. Unemployment is the reflection of the time needed to build new specific human capital. ${ }^{4}$

\section{A theoretical framework}

The framework that we apply is the continuous time Blanchard-Yaari overlapping generation model, see Blanchard (1985). Cohorts enter the labour force at a particular date. To keep the framework as simple as possible, we do not allow for retirement as

Table 1 The impact of financial crises on a number of key variables

\begin{tabular}{lrr}
\hline Variable & Peak to trough (\%) & Duration (years) \\
\hline Income per capita & -9 & 1.9 \\
Unemployment rate & 7 & 4.8 \\
House prices & -36 & 6.0 \\
Stock prices & -56 & 3.4 \\
Sovereign debt & 86 & 3.0 \\
\hline
\end{tabular}




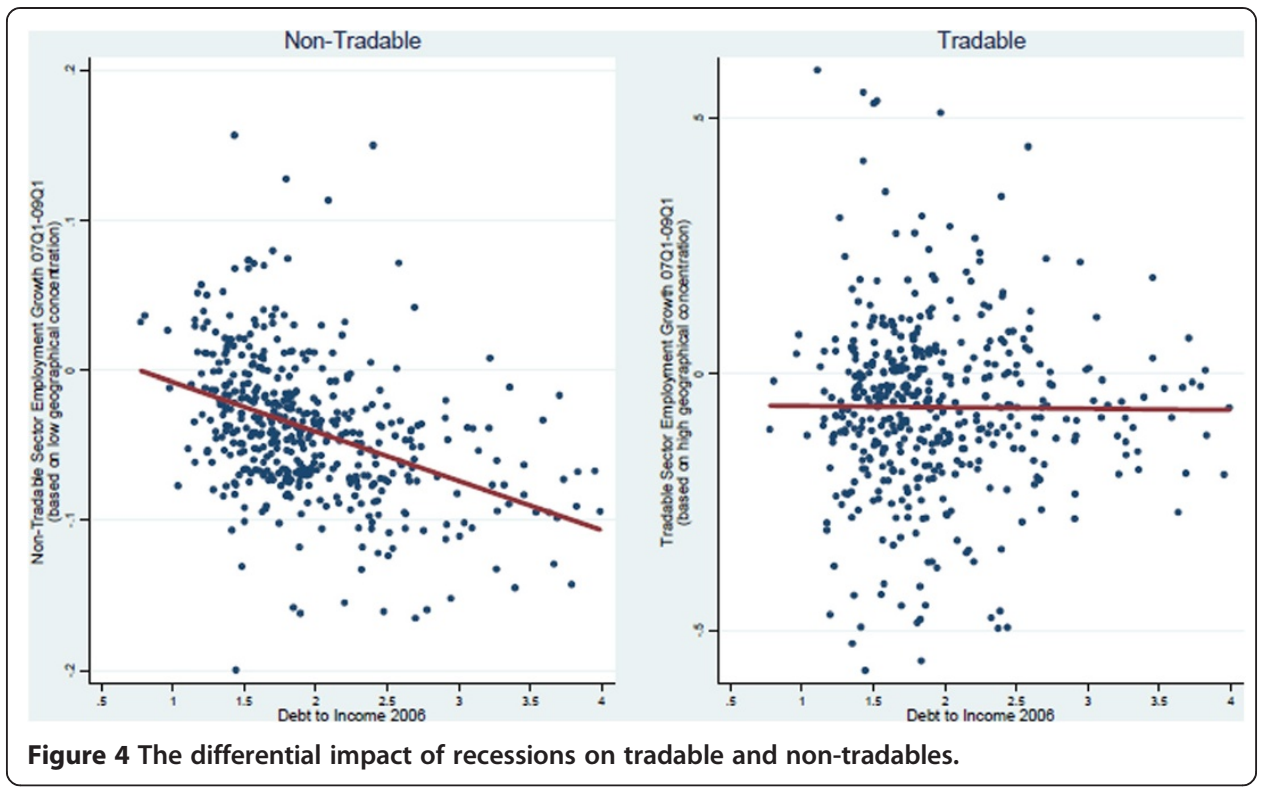

this does not affect the main argument. People work till they die. Every period, a fixed share $d$ of a cohort dies; $d$ is therefore the inverse lifetime of the worker or the inverse length of working career. We discuss the values of the parameters in our framework as to get an idea about the order of magnitude of various effects. As a fair compromise between life-expectancy and the length of a working career one can think of $d$ as $d=1 / 50$ years $=2 \%$ per year. We ignore population growth or changes in productivity. Each cohort runs a system of perfect life-insurance: the assets of the fraction $d$ of the cohort that dies are distributed among the surviving members of the cohort. Hence, there are no bequests to younger generations and each generation fully depletes its own wealth. Apart from their date of birth, all workers are identical.

Generations spend their income on three types of consumption: tradables, domestics, and housing services. They have a Cobb Douglas intertemporal utility function, implying that they spend a fixed share of their lifetime wealth every period and that they distribute that spending among the three commodities in fixed proportions. There is no renting sector in this economy. Workers enter the market without any wealth. At the beginning of their career, they buy a house which they fund with a mortgage. We assume that people can get full funding for their purchase, hence ignoring collateral constraints. Hence, after buying a house, the balance sheet of the new cohort contains the value of their human capital (the net present value of their expected labour income) and their house on the credit side and their mortgage debt on the debit side. Since the latter two cancel, the net wealth of a newly entering cohort is equal to its human capital.

Corresponding to the three types of consumption, production takes place in three industries: tradables, domestics, and construction. Productivity is normalized to unity. The tradable industry's output can be sold on the world market. When home demand for tradables so requires, this commodity can also be imported. The demand for tradables is infinitely elastic and its price is normalized to unity. Since productivity is equal to unity, since all markets are perfectly competitive, and since there are no other factors of production, wages in the tradable industry are equal to unity. This set up where the 
nominal price level is fully determined at the global market fits the context of EMU, where the price level for each member state is set by the ECB. Since wages and prices are fully flexible, this does not affect relative prices, but it does affect the denomination of the economy's public and private debt. De Grauwe (2011) argued that this is the main difference between the UK and Spain: the former can change the real value of its debt by a devaluation of its currency, the latter cannot. Contrary to tradables, domestics can only be consumed within the country. Neither tradables nor domestics can be stored for future consumption. Finally, a house is made up of two parts, land and the building. The supply of land is fixed. Land does not require any maintenance. The building depletes at a fixed rate $a$, let us say $a=2 \%$ per year. Apart from housing, there is no other physical capital. In steady state equilibrium, a fall in the demand for housing services will lead to a lower price for the land and a lower quantity of building.

The capital market of the monetary union is fully unified. Both the government and the private sector have full access to financial markets at the going interest rate $r$. Since we abstract from growth by keeping labour supply and productivity constant, the relevant rate is the difference between nominal interest rate and nominal growth. We use $r=2 \%$ per year. For simplicity, workers use the same discount rate for the calculation of net present value of their human capital. Since productivity and hence wages are normalized to unity, the value of human capital satisfies:

$$
\text { Value of human capital }=1 /(d+r)
$$

Due to the perfect life insurance scheme that allows each cohort to consume the wealth that it 'inherited' from its deceased members, a generation can consume a fraction $d+r$ of its wealth without depleting it: $r$ accounts for the interest revenues, $d$ for the 'inherited' wealth paid out by the life insurance scheme. Since this relation applies to all generations alike, total consumption is a fixed proportion of aggregate wealth:

Total consumption $=(d+r) \times$ Aggregate wealth

Hence, the marginal propensity to consume from wealth is $4 \%$, in line with the evidence reported by Case et al. (2013). As long as the economy is in steady state, aggregate wealth is equal to the value of human capital, since housing wealth and mortgage debt cancel. Hence, the value of consumption is equal the value of production. However, after a fall in house prices, aggregate wealth is less than the value of human capital. From equation [1] and [2] above, it easy to see that total annual consumption falls below the value of production by $(d+r) \times$ Fall in housing wealth. That is equal to $4 \%$ of the fall in housing wealth. Generations entering the market after the fall in house prices do not suffer from this negative wealth effect. A fraction $d$ of the old generations dies every period and is replaced by new generations who have not suffered from the decline in house prices. Let $t$ denote time elapsed since the financial crisis. Then, the time path of the negative effect on consumption reads:

$$
\text { Effect on consumption at time } t=(d+r) \mathrm{e}^{-d t} \times \text { Fall in housing wealth }
$$

The effect will be the largest at the moment that the crisis hits, and will decline exponentially to zero afterwards. 
In steady state equilibrium, the cost of housing services are equal to interest rate times the total value of the estate (land + building) plus the depreciation rate times the value of the building. This cost should be equal to share of housing services in total consumption in the Cobb Douglas utility function. A financial crisis will move the economy of its equilibrium path. House prices are temporarily below their new equilibrium value. When bidding for a house, people form expectations about the future path of house prices. If there were no capital market constraints that limit the availability of credit, buyers would pay higher house prices when house prices are expected to rise in the future, as future wealth gains offsets current excess expenditure. In theory, this effect should dampen house price fluctuations, making it hard to rationalize the fall in house prices observed in the Netherland in the first place. The availability of credit seems therefore to be a binding constraint in the aftermath of a financial crisis. The initial effect on house prices due to the combination of the fall in productivity, the reform of tax deductibility of mortgage interest, and austerity policies might therefore be ameliorated by a financial multiplier: lower house prices lead to lower credit, which puts further pressure on house prices. We leave this issue open here, and just take the fall in house prices as given.

The government does four things in this framework. First, it employs part of the workforce as civil servant, e.g. in health care and education. Second, it pays interest on its debt. Third, it collects consumption taxes. Taxes lead to a loss of efficiency due to tax evasion, e.g. by reducing labour supply. Like any Harberger triangle, these losses increase quadratically with the tax rate. Finally, the government runs a mortgage subsidy scheme.

Since people make their lifetime consumption-plan conditional on their expectations on future productivity and future taxes, there has to be a credible commitment to a path of future taxes. The simplest case is when the economy is in a steady state. Then, the tax rate can be maintained at its current level without public debt either im- or exploding. Steady states can be easily calculated for this economy. There are many, depending on the level of public debt. The higher public debt, the higher the interest payments a country has to make. This leaves less means for consumption. Hence, the higher public debt, the higher taxes and the share of the workforce that has to work in the tradable industry.

We apply this framework to analyse the adjustment path of a country to a one time shock, a financial crisis. Though we shall use the risk of future shocks as an argument for imposing constraints on the adjustment process, this risk is not modelled explicitly. Hence, after the unexpected shock, there is no uncertainty left about the future path of productivity. Moreover, policymakers can commit to their future policy. After the crisis, workers and policymakers live therefore in an ideal world of perfect foresight about future productivity and future fiscal policy.

Most macro-economic models require some form wage or price rigidity that prevents markets from clearing. This seems to be a prerequisite for a model with unemployment. Yet, in the framework applied here, wage or price rigidities are not strictly required. Instead, unemployment is interpreted as the time needed to acquire new industry specific human capital when entering a new industry. Mostly, workers acquire this human capital at the start of their career and never change industries. Hence, a new cohort starts unemployed. Each period, a share $l$ of the unemployed manages to 
acquire this industry specific human capital. Hence, $l$ is the inverse duration of unemployment. However, after a financial crisis, product demand shifts away from domestics to tradables. If this shift is large enough, workers prefer quitting their current industry and retraining for another industry above staying in their current job at a lower wage. Unemployed are free to choose in what industry they want to specialize. Reinhart and Rogoff's evidence on the persistence of unemployment after a financial crisis suggest $l$ to be 0.25 : it takes the average worker about 4 years to retrain for another industry. In practice, the Cobb Douglas utility function allows too much substitution in consumption between industries. Hence, accepting a lower wage in your current job is usually a more attractive strategy than switching to another industry. Hence, we work with a model where wages are fixed. Hence, the economy responds to a fall in the demand for an industry's output by a reduction in employment, not in wages.

This set up of an economy with three industries captures the main mechanisms at work after a financial crisis has wiped out part of a country's wealth. Current cohorts have seen their wealth evaporating, partly directly by the financial crisis, partly by the endogenous response of house prices and fiscal policy. Hence, they reduce their consumption as to satisfy their lifetime budget constraint. This reduces domestic demand for all three industries' output. For tradables, this is no problem, since it can sell its output on global markets at a constant price. For construction and domestics, however, this leads to a fall in demand. Wages in construction are determined by a non-arbitrage condition. Since productivity in all industries is normalized to unity, house-prices are equal to the gross wage in construction. Hence, the value of the specific human capital of workers employed in construction and domestics falls, leading to a fall in employment by not hiring replacements for the workers in the industry that die (=retire). If the fall in consumption is big, construction and domestics will even fire a share of its workforce, which then becomes unemployed to acquire the new specific human capital needed for finding employment in the tradable industry. Only when these cohorts who have experienced a wealth loss due to the financial crisis gradually die out, consumption recovers and hence employment in the domestic and construction industry.

\section{What explains the Dutch recession?}

What does this framework have to say about the recession that hit the Netherlands in the aftermath of the financial crisis? We assume that the economy was in steady state before the financial crisis hit, except for the fact that it ran it excessively generous system of tax deductibility of mortgage interest that had lost its credibility. As discussed in Section 2, people might dispute this assumption, claiming that housing was overvalued anyway. As said, we find it hard to square that with the empirical evidence.

The financial crisis has affected the Dutch economy along three canals. First, there was an aggregate loss of output/productivity, almost throughout the Western world, as discussed in Section 2. It is unclear what part of the reported output loss can be ascribed to an "exogenous" financial shock, coming unexpectedly, and what part is due to the endogenous mechanisms described below. We take $5 \%$ productivity loss as a reasonable number for the "exogenous" initial impact. It is about the fall in gdp relative to trend all six countries listed in Figure 1 experienced in 2009. Other things equal, a permanent $5 \%$ productivity loss implies that consumption should go down by $5 \%$. This 
also applies to the consumption of housing services. Since we assume that the economy is in steady state before the crisis hit, this implies that after the hit, the stock of housing was $5 \%$ above its steady state.

The second impact of the crisis was an increase in sovereign debt. The Netherlands had to buy back parts of ABN/Amro which had been acquired shortly before by Fortis bank. Furthermore, there have been support operations for other banks and insurance companies. However, some of these operations had no long run effect on sovereign debt, as they turned out to be profitable. Apart from the cost of saving banks, there was an initial loss of tax capacity in 2009, which is likely to have been more costly than the cost of saving banks. Altogether, the increase in public debt from $45 \%$ in 2007 to 60\% in 2009 might be a reasonable proxy for the "exogenous" effect of the crisis, while the subsequent increase to $75 \%$ is likely to be due to "endogenous" mechanisms described below.

The third impact was the hit to the credibility of the system of mortgage deductibility. The generosity of the system has been discussed in Section 2. Polls in the period preceding the financial crisis revealed that the system was losing credibility anyway. The public expected changes in the system. The crisis gave it a final blow. In the 2012 coalition agreement, parties negotiated a trimming of the system such that the user cost of housing services went up by about 10\%, see CPB (2012). The macro-economic implications of this policy have been gravely underestimated by the government. When housing supply is completely inelastic, house prices capture the net discounted value of all future entitlement to mortgage subsidies. A balanced budget reduction of the tax deductibility -the decline in government expenditure on the tax deductibility is ploughed back to tax payers by a reduction in tax rates one-for-one- is still going to hurt current generations of home owners. The value of their property goes down, reflecting the net present value of the reduction of future tax deductibility. Future generations benefit, since their loss of mortgage subsidies is exactly offset by the fall in house-prices, while they still benefit from lower taxes.

A balanced budget reduction of the tax deductibility is therefore equivalent to a wealth-transfer from current to future generations. Simple calculations suggest that this transfer is massive. The value of the total stock of housing is about $200 \%$ of gdp. When supply is fixed, a 10\% increase in the user cost of housing reduces house prices by $10 \%$. Hence, this implies a wealth transfer from current to future generations of $10 \% \times$ $200 \%=20 \%$ of gdp. Using the initial level of public debt of $45 \%$ in 2007 as a benchmark, this equivalent of servicing $20 \% / 45 \%=45 \%$ of this debt by the reform of the system. Allowing for some price-elasticity of housing supply mitigates part of this, but given the low depletion rate of real estate, $a=2 \%$, the adjustment of the stock of housing is slow.

Wrapping up the previous discussion, the initial effect of the financial crisis on the Dutch economy has probably been threefold: (i) 5\% drop in permanent drop in productivity, (ii) $15 \%$ of gdp increase in sovereign debt, and (iii) a loss of credibility of the system of mortgage subsidies leading to an increase in the user cost of housing by $10 \%$.

How could fiscal policy have responded to this challenge? Since the economy was in steady state before the crisis hit, a continuation of the old policy was infeasible. Sovereign debt has gone up by $15 \%$ of gdp, so the minimum requirement would be to raise taxes to generate the additional revenues needed for covering the interest on this higher debt. 
From a tax smoothing perspective, this policy of raising taxes just to cover the additional interest payments would be the optimal response. Tax rates would immediately jump to their new steady state. Any ambition to raise taxes temporarily above their steady state level to undo at least partly the increase in sovereign debt would violate the principle of tax smoothing, since initially taxes exceed their new steady state level. However, accepting the increase in sovereign debt as a permanent phenomenon would be too low a level of ambition for policy makers. It would imply the rise in sovereign debt to be permanent, leaving the country in a more vulnerable state when a future shock would hit the economy. It would turn sovereign debt into a random walk, where each new downward shock would lead to a permanent increase in the debt. Instead, we take as a point of reference that policy makers want the debt to revert to its pre-crisis steady state level, that is, $45 \%$ of gdp. If we impose this as a constraint on fiscal policy, the question that remains is: what is the optimal speed of adjustment? We sketch the reasons why policy makers will easily be overambitious in their effort to get the debt back to the old steady state.

How does the economy respond to the combination of shocks discussed above? The permanent fall in productivity by $5 \%$ implies that the current supply of housing exceeds the new steady state level of demand by $5 \%$. The collapse of the credibility of the mortgage subsidy system and the policy response to that lead to a further decline of the steady state demand for housing by $10 \%$. Hence, initial supply exceeds steady state demand by $15 \%$. This excess supply will only disappear by gradual depletion of the existing stock and lower new construction.

The excess supply leads to a fall in house prices and hence a fall in the financial capital of current cohorts. Future cohorts are not hurt, because they will buy their house after the fall in house prices. Due to the no-arbitrage condition, the decline in house prices leads to an equal fall in gross wages in construction. This leads to a decline in the human capital of workers in construction. However, this effect is only second order compared to the effect of declining house-prices on financial capital, since in steady state the wage bill of construction is equal to the rate of depletion of housing times the value of the stock of housing and since the depletion rate is only $2 \%$. Again, future cohorts are not hurt, since they seek employment elsewhere, in tradables. The fall in both human and financial capital reduces the wealth of current generations. Since their lifetime budget constraint has to be satisfied, they must reduce their consumption. Their response will be to spread the reduction evenly over their entire lifetime. This smoothing dampens the impact on current consumption, but given the high value of the stock of housing, the effect is still substantial. Smoothing implies that the effect on consumption is highly persistent. It fades away only by current cohorts dying and being replaced by new cohorts. This occurs at a rate $d=2 \%$ per year, see equation (3) in Section 3, so it takes a decade or more before this has a substantial impact. The fall in consumption reduces the demand for housing temporarily below its steady state level, thereby increasing its excess supply. It also reduces the demand for domestics below its steady state level, reducing the value of human capital for workers employed in this industry. Since empirically the domestic industry is three to five times as big as construction, its effect on total wealth is bigger than the effect on the human capital of construction workers. Lower total wealth will further reduce lifetime consumption of currently living generations. 
The government raises taxes to cover additional interest payments and to move public debt back to its pre-crisis level. This further reduces wealth and hence lifetime consumption. The high tax rates today compared to tomorrow lead to substitution effect in consumption, inducing a further shift of consumption towards the future. The temporary fall in consumption has a negative effect on the tax revenues. The important point is the relevant time frame of the phrase 'a temporary fall in consumption': it takes a decade or more before a substantial part of the fall in consumption is undone by new generations entering the market and hence for tax revenues to catch up. Sovereign debt will go up in the first decade after the crisis, more or less independent of what fiscal policy will be.

Whether the government levies a consumption or an income tax makes little difference for the size of this effect. On the one hand, the time-path of revenues will be more robust for an income rather than consumption tax since extra savings (i.e.: the trade surplus) are taxed immediately in an income tax regime. On the other hand, income is more volatile than consumption due to consumption-smoothing. Income will be low initially due to the cost of reallocation of labour from construction and domestics to tradables.

Relative to the fall in productivity and the collapse of the credibility of the mortgage subsidy system, the increase in sovereign debt by $15 \%$ of gdp contributed relatively little to the problems of the Dutch economy. The real interest payments are only $2 \% \times$ $15 \%=0.30 \%$ of gdp ( $=1$ billion). Repaying this additional debt in 30 years would require an increase in the structural surplus $0.60 \%$ ( $=4$ billion).

The mechanism discussed in this section explains why hasty austerity is costly. The welfare loss will predominantly fall on those who own a house at the moment the financial crisis hits the economy. It leads to overshooting in the reallocation of labour from domestics and construction to tradables. The greater the share the burden that is shifted to future generations, the smaller the required temporary fall in consumption below its steady state level and hence the lower this overshooting in construction and domestics. Since this overshooting reduces the value of the specific human capital invested in these industries, it is costly. Hence, shifting part of the burden to future generations reduces the total cost of adjustment. Since taxation yields externalities in the form of deadweight losses, speedy austerity might even be Pareto inefficient, in the sense that it is to the detriment of all generations. Without a numerical analysis, we cannot tell whether this is currently the case in the Netherlands.

\section{Comparison to other countries}

How does this analysis relate to the recent experience in other countries? Can this framework provide a story for what happened to the GIPSI countries? Or can it explain why Germany did not suffer from the problems the Netherlands experiences? In both cases, the assumption we made on the Netherlands that the country was in steady state at the onset of the crisis in 2008 is likely not to be unjustified for other countries. The GIPSI countries were at a path of excessive consumption. The story differs somewhat between countries. For example, Ireland and Spain were experiencing a housing boom. Partly, these booms were a rational response to rapid gdp-growth in the preceding period. But for main part, they were examples of irrational exuberance. These booms lead to an excessively large construction industry, which had to be sized down anyway, 
since the industry was way above its steady state size. Then, costly adjustment is unavoidable. However, by not providing intergenerational insurance, adjustment will overshoot, just as discussed in the paper. Hence, there is a limit to amount of immediate austerity that is helpful even for these countries, also from the perspective of foreign creditors who want their loans to be repaid.

Why did Germany fare so much better than the Netherlands? Probably, the country was not in steady state either. The Hartz reforms of the labour market in the period 2002-2006 gave the German economy an enormous boost, more or less similar to what happened to the Netherlands after its labour market reforms a decade earlier. The growth in gdp and hence in total disposable income have pushed up consumption and hence the demand for housing, again, similar to what happened to the Netherlands a decade before. Hence, where there was excess supply of housing in the Netherlands after the crisis (due to the productivity fall and due to loss of credibility of the mortgage interest tax deductibility system), the effect of the financial crisis was more or less offset by the boost of the economy due to Harz reforms in Germany.

One can ask to what extent our analysis is affected by wage rigidity. What role does wage rigidity play in this model? With fully flexible wages, unemployment would rarely occur. To understand why, one must keep in mind that people only prefer a spell unemployment/retraining lasting on average 4 years if this cost outweighs the income loss in the current industry. The loss in lifetime earnings would be $100 \%$ of the net present value of 4 years of income when deciding to retrain. This is equivalent to a $40 \%$ lower wage over a period of 10 years. Due to the Cobb Douglas preferences, the fall in prices in domestics at constant employment (=output, since we normalized productivity to unity) will have to be equal to the fall in demand. It will therefore take a deep crisis in demand for domestics to fall that much. Note that in this case, unemployment is efficient. It is better for workers to leave the industry than to stay in their current industry waiting for a recovery of their wages: the value of unemployment exceeds the value of sticking to the current job. Hence, wage flexibility leads to a slow, but efficient adjustment process, where in particular construction will not hire new workers over a long period of time.

Without wage flexibility, each industry operates on its labour demand curve, but not on its supply curve. Employers will respond to a fall in demand by firing workers, since they are unable to adjust cost. This is inefficient, since the continuation value of the current job is higher than the value of unemployment. Lack of wage flexibility leads to a quick, but costly adjustment process. Hence, expansionary fiscal policy will be more valuable in a world with fixed rather than with flexible prices, since the reallocation of labour is more costly in the absence of wage flexibility and limiting the amount of overshooting therefore yields a higher pay off.

\section{Conclusions}

The analysis of the fiscal policy response to the Dutch recession has a wider relevance. It provides general lessons for fiscal policy in the aftermath of a financial crisis with a house-price slump. It also provides lessons for the European regulatory framework for supervision of its member-states' fiscal policy. This section summarizes these lessons.

Lesson 1 is that house-price slumps imply a transfer of wealth from current to future generations. Current generations lose and have to trim down their consumption to 
satisfy their lifetime budget constraint. Future generations gain since they have to pay the current generation a lower price for its housing property. This wealth-transfer is massive. Assuming the value of the stock of housing to be about twice gdp, a $30 \%$ fall in house-prices implies a wealth-transfer to future generations of $60 \%$ of gdp. Trimming down mortgage subsidies is equivalent to forcing house prices to fall and therefore implies a wealth transfer between generations. Again, this transfer is substantial.

Lesson 2 follows immediately from Lesson 1. Since high house prices are equivalent to a wealth-transfer between generations, they are equivalent to public debt. A fall in house prices is therefore equivalent to a fall in public debt. Again, this effect is massive: the total loss in the value of residential real estate in the Netherlands is about equal to its public debt. So, the current generation of home-owners has since 2008 involuntary transferred an amount of wealth to future generations equal to the total stock of public debt. That being the case, fiscal policy might better provide intergenerational insurance to offset part of this transfer. Stated differently, house-price slumps and austerity should be substitutes, not complements. This is an application of ideas laid out in Teulings (2012), see also Buiter (2010). Hence, it is not necessarily bad for public debt to increase in the aftermath of financial crisis with a house-price slump. If fact, this is even hard to avoid.

Lesson 3 is that not the level but the volatility of house-prices is the variable to worry about. The cost of house-price slumps (and of austerity for that matter, they are similar, see Lesson 2) is the reallocation of labour from construction and domestics to tradables. This reallocation leads to a loss in industry specific human capital and unemployment. Good macro policy, therefore, stabilizes house-prices as to avoid prolonged periods of high unemployment. The main reason why high house prices are a problem is that they increase the likelihood of future house-price slumps and hence a reallocation of labour away from construction and domestics. Similarly, low house prices are a problem mainly because they increase the likelihood of a future boom, leading an opposite reallocation with a loss industry specific human capital (in this case in tradables, a phenomenon known as the Dutch disease).

Lesson 4 regards the time horizon for fiscal policy. Fiscal policy tends to be discussed in a rather short run framework, usually a time horizon of about 4 years. The overlapping generations framework applied here suggests that this horizon is far too short. The main role of fiscal policy is to provide intergenerational insurance so that the part of the burden of today's financial shock can be shifted to future generations. This role requires fiscal policy to take a long run stance, a decade at a minimum. In fact, the periodicity of the ratio of public debt to gdp is quite long empirically.

Lesson 5 draws the conclusion from Lesson 4. Quite often people make a plea for quick and tough austerity. They have in mind the analogy of drawing a plaster from the skin. Doing it quickly is painful, but only for a short moment. After that, one can start afresh. Fiscal policy must be similar, so the implicit reasoning goes. This analogy is false: quick austerity leads to overshooting in consumption and hence in a costly reallocation of labour from construction and domestics to tradables. The loss of industry specific human capital and the high unemployment associated with it is the main component of the cost of a recession. A pre-announced gradual approach works better. Wage flexibility reduces the need for labour reallocation by enabling declining industries to gain market share by cutting cost. Low unemployment benefits speed up adjustment by improving the 
incentives for the acquisition of new human capital. However, some degree of intergenerational insurance by a proper fiscal policy can reduce the need for costly labour reallocation in the first place.

Lesson 6 is that the short run effect of austerity on the public debt ratio and in extreme cases also on the deficit might well be upward. Austerity further reduces wealth in the hand of current generations, which reduces consumption and therefore the tax base. In some cases, this upward effect might be inevitable. If consumption was above its steady state level (as in the case of GIPSI countries), then reallocation of employment is necessary anyway. However, even then there is a point beyond which further austerity leads to excessive overshooting. A similar reasoning applies to the level of public debt. The short run effect of austerity might well be to increase public debt.

Lesson 7 is a direct implication of Lesson 6 . Since the immediate effect of austerity might be an increase the deficit or public debt, both variables are inadequate control variables for fiscal policy. A policy based on these control variables is destabilizing. In particular, when policymakers underestimate the cost of austerity, as Blanchard and Leigh (2013) show to have been the case in 2010, then this policy might lead to a sequence of austerity rounds, each of them falling short of the desired short run effect.

Lesson 8 is that the EU regulatory framework is inadequate. Since the budget deficit and the level of public debt are inadequate control variables, a framework using these variables must fail. The idea of a binding regulatory framework with sanctions for those countries which do not adhere to its rules might work, but such a framework should be based on different control variables.

Lesson 9 is that the concepts of an output gap and structural deficit have to be reconsidered. The control variable actually used in the European regulatory framework is the structural deficit, which corrects the actual deficit for cyclical effects using the output gap. Control variables should grounded more firmly in concepts derived from generational accounting, extending the work by Auerbach, Gokhale, and Kotlikoff (1994), accounting for the effect of house-price slumps and changes in the mortgage subsidies on the intergenerational wealth distribution, see Van Ewijk and ter Rele (2008).

Lesson 10 is that the same lessons that apply to a reform of a system of tax deductibility of mortgage interest also apply to structural reforms, see Teulings and Zubanov (2013). Many market distortions create rents of which the net present value can be traded on the market. For example, the value of a permit to drive a cap is equal to net present value of all future rents that it yields. The ability to trade this permit allows the current holder of the permit to extract the net present value of all future rents. Future owners get nothing: the price of the permit offsets the net present value of the rents. Hence, reforms aiming at a reduction of these distortions change the intergenerational distribution of welfare in favour of future generations. Offsetting these intergenerational effects by an expansive fiscal policy would improve the chances of success in structural reforms.

\section{Endnotes}

${ }^{1}$ The table lists long term household debt, but this is almost exclusively mortgage debt.

${ }^{2}$ This system provides one explanation for the large size of the Dutch long term private debt relative to its GDP, only Denmark having a larger number, $124 \%$ and $134 \%$ of gdpde respectively versus $61 \%$ for the EU on average. The other explanation is that the Netherlands has an extensive pension system. Hence, Dutch households (again, similar 
to Denmark) have a high pension wealth, which however is illiquid and therefore cannot be used to finance the purchase of housing. Pension wealth is $185 \%$ for the Netherlands and $128 \%$ for Denmark, compared to $59 \%$ for the EU on average, see Social and Economic Council (2013, Table two).

${ }^{3}$ This was confirmed by my personal conversations with the party leaders of most major political parties in the Netherlands being the president of CPB, the Dutch fiscal watchdog. Having pointed out to one of the party leaders that his election platform entailed too much austerity, his reply was that he knew but that that was inevitable. "behavior".

${ }^{4}$ One might argue that most unemployed spend little time on schooling. However, industry specific human capital might be acquired in an informal way, by the unemployed getting social networks in the expanding industries or by employers in the tradable sector requiring some time to realize that the crisis in the domestic sector offers new opportunities for their industries.

Competing interests

The IZA Journal of European Labor Studies is committed to the IZA Guiding Principles of Research Integrity. The author declares that he has observed these principles.

Responsible editor: Martin Kahanec

Received: 2 December 2013 Accepted: 14 August 2014

Published: 10 Oct 2014

References

Auerbach AJ, Gokhale J, Kotlikoff L (1994) Generational accounting: a meaningful Way to evaluate fiscal policy. J Econ Perspect 8(1):73-94

Bénétrix AS, Eichengreen B, O'Rourke KH (2012) How housing slumps End. Econ Policy 72:649-692

Blanchard OJ (1985) Debt, deficits, and finite horizons. J Polit Econ 93(2):223-247

Blanchard OJ, Leigh D (2013) Growth forecast errors and fiscal multipliers. IMF Working Paper WP/13/1

Brender A, Drazen A (2005) Political budget cycles in New versus established democracies. J Monet Econ 52(7):1271-1295

Brender A, Drazen A (2008) How do budget deficits and economic growth affect reelection prospects? Evidence from a large panel of countries". Am Econ Rev 98(5):2203-2220

Buiter WH (2010) "Housing wealth isn't wealth", economics - The Open-Access, Open-Assessment E-Journal. Kiel Institute for the World Economy 4(22):1-29

Case KE, Quigley JM, Shiller RJ (2013) Wealth effects revisited: 1975-2012. NBER Working Paper 18667

Cerra V, Saxena SC (2008) Growth dynamics: the myth of economic recovery. Am Econ Rev 98(1):439-457

Commissie Sociaal-Economische Deskundigen (2010) Naar een integrale hervorming van de woningmarkt. Social and Economic Council, The Hague

CPB (2012) Gevolgen van het huurbeleid nader bekeken. Memorandum, 10 December 2012

De Grauwe P (2011) The governance of a fragile eurozone. University of Leuven, discussion paper. http://www.econ. kuleuven.be/ew/academic/intecon/Degrauwe/PDG-papers/Discussion_papers/Governance-fragile-eurozone_s.pdf

Mian AR, Amir S (2010) Household leverage and the recession of 2007 to 2009. NBER Working Paper 15896

Mian AR, Amir S (2012) What explains high unemployment? The aggregate demand channel. NBER Working Paper 17830

Reinhart CM, Rogoff K (2009) This time is different, eight centuries of financial folly". Princeton University Press, Princeton/ Oxford

Social and Economic Council (2013) Dutch economy in calmer waters: a macro-economic exploratory survey. http://www.ser.nl/en/publications/publications/2013/dutch-economy-in-calmer-waters.aspx

Teulings CN (2012) Fiscal consolidation and reforms: substitutes, not complements. Vox Eu, 13 September

Teulings CN, Zubanov N (2013) Is economic recovery a myth? robust estimation of impulse responses". J Appl Econ

Van Ewijk C, ter Rele H (2008) Macro-economische verkenning van de huizenmarkt. In: Preadviezen. Koninklijke Vereniging voor de Staathuishoudkunde, SDU Uitgevers, Den Haag (in Dutch). http://www.kvsweb.nl/nl/webmanager/userfiles/file/ Preadviezen\%202008.pdf

10.1186/2193-9012-3-20

Cite this article as: Teulings: Unemployment and house price crises: Lessons for Fiscal Policy from the Dutch Recession. IZA Journal of European Labor Studies 2014, 3:20 